\title{
Mojca Šorli
}

Trojina, Institute for Applied Slovene Studies

Ljubljana, Slovenia

\section{Corpus-Based Lexicographical Descriptions with a Special Focus on Pragmatics: The Case of the Slovene Lexical Database}

\begin{abstract}
Summary
The present paper focuses on ways in which the pragmatic (functional) meaning that arises from various contextual features, known in corpus linguistics as semantic prosody, can become an integral part of lexicographical descriptions as they are represented in the Slovene Lexical Database (SLD). This is particularly important for the treatment of phraseology and idiomatics. First, the theoretical background is provided, with the focus on the prototype theory and its practical implications for monolingual lexicography. A parallel is drawn with the model of meaning analysis in the SLD. The second part begins with a brief introduction to semantic prosody and continues with an analysis of monolingual meaning descriptions in the SLD against a number of authentic corpus examples, investigating how their pragmatic components have been identified. The analysis of corpus data shows that pragmatics is an important contributor to the process of sense discrimination in works of lexical and lexicographic relevance.
\end{abstract}

Key words: lexicographical description, lexical database, pragmatics, semantic prosody, phraseology

\section{$\mathrm{Na}$ korpusu temelječi leksikografski opisi s poudarkom na pragmatiki: Leksikalna baza za slovenščino}

Povzetek

$\mathrm{V}$ prispevku raziskujemo načine, na katere pragmatični (funkcijski) pomen, ki izhaja iz raznolikih značilnosti sobesedila in situacijskega konteksta in ki ga v korpusnem jezikoslovju imenujemo semantična prozodija, postane sestavni del leksikografskega opisa, kot ga predpostavlja Leksikalna baza za slovenščino (LBS). To je še posebej pomembno pri obravnavi frazeologije in idiomatike. Najprej predstavimo teoretski okvir, v katerem se osredotočimo na teorijo prototipa in praktične implikacije za enojezično leksikografijo, ki iz nje izhajajo. V nadaljevanju potegnemo vzporednico z modelom pomenskih opisov v LBS. V začetku drugega dela na kratko predstavimo semantično prozodijo, nato $\mathrm{z}$ vidika pragmatičnega pomena analiziramo izbrane pomenske opise iz LBS $\mathrm{s}$ pomočjo avtentičnih korpusnih zgledov, na podlagi katerih so nastali. Analiza korpusnih podatkov kaže, da je pragmatični pomen mogoče prepoznati kot pomemben razločevalni dejavnik v postopku pomenske členitve v leksikalnih in leksikografskih opisih.

Ključne besede: leksikografski opis, leksikalna baza, pragmatika, semantična prozodija, frazeologija 


\section{Corpus-Based Lexicographical Descriptions with a Special Focus on Pragmatics: The Case of the Slovene Lexical Database}

\section{Introduction}

\subsection{The Sinclairian lexicographical tradition}

John Sinclair's work was partly founded on Halliday's work (according to Hanks 1994); in particular, they shared a conviction that there is no clear distinction between grammar and lexis, and a belief that, as Halliday suggests, it is necessary to "supplement the grammar by formal statements of lexical relations" (1966). Also, it was Halliday who elaborated on the idea of meaning potential rather than meaning as an objective entity conceived of in terms of traditional necessary and sufficient conditions, which had ruled lexicographical practices for centuries. Rather than talking about what words mean, we now talk about what meaning potential words have, depending on their linguistic context. Another realisation in the study of lexis with far-reaching consequences for lexicography was that "[...] the lexical item is not necessarily coextensive on either axis [paradigmatic or syntagmatic] with the item, or rather with any of the items, identified and accounted for in the grammar" (Halliday 1966), and "[...] the grammatical complexity can be avoided by recognising a lexical item let in for (he let me in the other day for a lot of extra work) without demanding that it should carry any grammatical status. It is not suggested, however, "that such non-coextensiveness between the items of grammar and those of lexis is the norm, but merely that for certain purposes it is useful to have a descriptive model of language that allows for it" (ibid.).

Furthermore, Halliday's views $(2007,26)$ of the definitions and explanations that should be given in dictionaries were well reflected in the COBUILD definition style (see 1.2). The basic idea was that dictionary definitions can and should provide a paraphrase or explanation of meaning whereby "the meaning is not necessarily fully contained or exhaustively captured within such a definition" (ibid.).

\subsection{The prototype theory}

The notion of conceptual prototypes was first presented in 1971 by Eleanor Rosch, and it has been written about extensively since then. According to Hanks (1994), the best account of the prototype theory for lexicographical purposes was provided by Taylor (1989, 59-60): "The prototype can be understood as a schematic representation of the conceptual core of a category .... Entities are assigned membership in a category in virtue of their similarity to the prototype; the closer an entity to the prototype, the more central its status within the category." COBUILD1, edited by Sinclair and Hanks in 1987, was the first, and by and large the only, dictionary to that point that had systematically taken into account prototype theory, as Hanks (1994) himself points out.

\subsubsection{Corpus Pattern Analysis (CPA)}

Drawing on the premises of the prototype theory, a project named Corpus Pattern Analysis ${ }^{1}$ was initiated by P. Hanks. The basic principle is to discover how exactly meanings arise from patterns of

http://nlp.fi.muni.cz/projekty/cpal . 
usage, rather than treating words as isolable elements of a structure. Associated with this is a theory of meaning in language called The Theory of Norms and Exploitations (TNE). ${ }^{2}$ CPA is based on a system that records the participant structure (=semantic roles) of a sentence pattern and provides a schematic explanation of the particular pattern (or implicature), thus establishing the relationships between the identified participants.

\subsubsection{FrameNet}

According to its author, CPA is also influenced by frame semantics (Fillmore and Atkins 1992) and is complementary to FrameNet. ${ }^{3}$ Frames or 'mental schemas' should be understood as prototypical descriptions of the (typical) features of a recurrent social event or situation. Such a schema contains features that can be inferred on the basis of our general knowledge, even if they have not been explicitly mentioned (Stubbs 2001, 439). FrameNet primarily builds ontologies and is concerned with the identification of semantic participants and argument structures by means of predetermined and largely formalised syntactic-semantic categories. Meaning descriptions in the Slovene Lexical Database, also called 'scenarios', though not formalised to the same extent, have been partly modelled on FrameNet in the way semantic roles have been assigned.

\subsubsection{COBUILD and other monolingual learner's dictionaries (MLDs)}

TNE in turn is a theory that owes much to Sinclair's work on corpus analysis and collocations (e.g., Sinclair 1987, 1991, 2004), and to the Cobuild project in lexical computing (Sinclair et al. 1987). CPA, FrameNet and the Cobuild project all influenced a number of decisions in the construction of the Slovene Lexical Database, particularly with their emphasis on the prototype theory.

In setting the guidelines for meaning descriptions, corpus-based and pragmatically aware contemporary monolingual dictionaries have been considered: COBUILD3, as well as LDOCE4, and MEDAL2. This range of foreign learner's dictionaries covers the core vocabulary of English and, more importantly, treats it with an emphasis on what is (proto)typical: where appropriate, MEDAL2, LDOCE4 and COBUILD3, as well as MWLD have been consulted in order to gain comparison of the ways in which they describe (pragmatic) circumstances.

\section{The Slovene Lexical Database (SLD)}

The kind of observations presented in the present paper can only be obtained in projects such as the compilation of a dictionary or a lexical database which involves a comprehensive and detailed study of most of the lexis of a particular language. As a monolingual lexical resource, the Slovene Lexical Database $(\mathrm{SLD})^{4}$ was designed to provide a corpus-driven account of the core vocabulary of the Slovene language, including semantic, syntactic, collocational and phraseological information, supported by illustrative examples from the 620-million-word FidaPlus reference corpus of Slovene. ${ }^{5}$ The SLD is constructed on the principles of lexicogrammar, giving more prominence

See Hanks 2013.

The project was started and has been run by Charles J. Fillmore, at Berkeley University of California (http://framenet.icsi. berkeley.edu/). CPA offers a systematic analysis of the patterns of meaning and use of each verb, unlike FrameNet, which provides an in-depth analysis of semantic frames. "Each CPA pattern can in principle be plugged into a FrameNet semantic frame" (P. Hanks, at http://nlp.fi.muni.cz/projects/cpa/).

4 Slovene Lexical Database (2008-2012): The database's operation was co-financed by the European Union, the European Social Fund, and the Ministry of Education and Sport of the Republic of Slovenia. It presently contains 2,500 entries.

5 www.fidaplus.net. 
to syntagmatics and meaning descriptions, ${ }^{6}$ perhaps intentionally somewhat at the expense of the description of the inherent features and paradigmatic associations of words. A great deal of thought has been given to the nature and form of lexicographical description as it should be provided in (learner's) dictionaries. Unlike a classical dictionary definition, which tends to describe the meaning of a 'word', an alternative method of compiling meaning descriptions has been adopted, in part integrating and adequately adjusting the principles of the COBUILD project, on the assumption that an explanation must illustrate, along with its lexical meaning, a broader linguistic context of the lexical item. The double nature of such descriptions is related to the dual information thus acquired, i.e., information on meaning and use, and presupposes full-sentence definitions. ${ }^{7}$ These ensure a more subtle presentation of meaning due to greater flexibility and a larger spectrum of descriptive options (Barnbrook 2002, 55). Ideally, a special methodology would be used to find evidence of pragmatic aspects of meaning; however, looking for pragmatic meaning is part of that same detailed examination of language use that leads to the identification of meaning potentials. As meaning descriptions in the SLD are entirely based on contemporary corpus data, the role of $\mathrm{SSKJ}^{8}$ was limited to comparison, double checking and certain specific consultations. Pre-corpus lexicographical descriptions generally included little or no pragmatic information. Still today, lexical databases and dictionaries overlook pragmatic meaning; specifically, in their definitions most contemporary dictionaries as yet fail to convey the complexities of semantic prosodies, typically implying them in the examples of (typical) usage. This strategy works well on the assumption that implicit information is lexicographically sufficient, but in the following paragraphs we will attempt to show that this is often not the case.

\subsection{The lexicographical descriptions in the SLD}

\subsubsection{General principles}

The treatment of lexical data in the SLD sets out to describe individual lexical items, their meanings and usage, which includes defining the range of semantic and syntactic combinatorial possibilities. The principles of non-coextensiveness (see 1.1.1) are observed at the syntagmatic level, particularly in relation to the identification of syntactic structures and patterns, but also within meaning descriptions in the identification of semantic arguments. These are assigned specific semantic types (lexical sets) without explicit reference to their syntactic functions. Subordinate to the level of argument structure are the levels of grammatical patterns, structures and collocations.

\subsubsection{The semantic-syntactic description}

Meaning descriptions in the SLD are schematically divided into two parts or levels:

a) The participant structure: the syntactic environment of the headword, i.e., all of the identified participants and circumstances are assigned semantic types or semantic roles, and are manually annotated. Syntactic and semantic information is overtly marked (obligatory participants are in block letters) in order to enable automatic retrieval of patterns of usage.

b) The 'scenario' is the level of description that states the general situation of meaning, the

Cf. http://www.webdante.com/. The SLD is closest in scope and methods to the recently compiled DANTE database, but in the present paper we choose not to confer with its meaning descriptions as they are in the form of preliminary glosses.

Pioneered by the COBUILD 1 project (1987).

8 The Dictionary of Standard Slovene, with around 100,000 headwords. 
relationships between the participants and other sense-discriminating, particularly pragmatic, components of meaning (Gantar et al. 2009, 108).

Obligatory vs. optional elements:

Each meaning description includes all of the participants and circumstances, i.e., all of the words, expressions and situations in the co-text that are needed to construct a particular meaning. Participants are identified as obligatory if in at least some contexts they are syntactically (or contextually) expressed, i.e., their instantiations are to be found in the corpus data.

\subsubsection{The conceptual framework: prototypical meaning in CLIMB and PLEZATI}

Referring to the theoretical literature, Hanks $(1994,242)$ quotes C. Fillmore (1982), who posits at least six ways in which semantic prototypes can be realised, exemplified by typical English words, e.g., Type CLIMB: "the category is identified in terms of a disjunction of mutually compatible conditions, and the best examples are those in which all members of the disjunction are present." Hanks also quotes Jackendoff (1990) on this point, who sees climbing as involving two different conceptual conditions: "(1) an individual is travelling upward; and (2) the individual is moving with characteristic effortful grasping motions, for which a convenient term is clambering ... [...] Actions that satisfy only one of the conditions [...] are somewhat more marginal but still perfectly legitimate instances of climbing."

At the highest level of analysis according to Hanks, climb appears in four usage patterns, which are identified based on "how various lexical sets in particular syntactic roles can alter the meaning of the target word" (Hanks 1994). The verb's valency slots have syntactic realisations - subject, direct object, prepositional object and adverbials - that in combination with semantic types and lexical sets determine the meaning. Although ultimately aiming for a similar result at the level of granularity, ${ }^{9}$ sense discrimination in the SLD proceeded in quite a different way, drawing on a set of theoretical concepts of which prototype is one. Semantic types and lexical sets are of primary importance; their syntactic functions, however, have not been established as relevant in determining the meaning potential. Non-coextensiveness (of grammatical and semantic units) has been taken as a default rather than as a possibility, the formal aspects of semantic-syntactic patterns being restricted to (shallow) syntactic structures (e.g., Adj + Noun, Adv + Inf-verb + Adj) and syntactic patterns (sb climbs, sb climbs over sth, sb climbs on sth, sb climbs from sth, etc.).

The above 'uses', which show subject, direct object and adverbial complement slots surrounding the verb, are rendered in the SLD by schematic meaning descriptions that, to an extent, resemble those of FrameNet. We thus acquire semantically and pragmatically informed 'implicatures' that provide a platform for further work on explanations and definitions tailored to the needs of specific target groups.

In the SLD, we adopted the so-called "splitters" approach (as opposed to the "lumpers" approach). The word's meaning potential can be accounted for with a few broad senses or be broken down into a number of "subsenses", each matching a precise context, which is what "splitters" do (Atkins and Rundell 2008, 268). 


\begin{tabular}{|c|c|c|c|c|c|}
\hline & $S$ & $\mathrm{~V}$ & comb. ${ }^{11}$ & $\mathrm{O}$ & A \\
\hline \multirow[t]{3}{*}{ (a) } & $\begin{array}{l}\text { Thing: } \\
\text { LS: HUMAN } \\
\text { LS: ANIMAL }\end{array}$ & $\begin{array}{l}\text { GO UPWARD } \\
\text { with effort } \\
\text { SLOWLY (?) }\end{array}$ & $\begin{array}{l}\text { USING ALL LIMBS } \\
\text { TO TOP OF (?) }\end{array}$ & $\begin{array}{l}\text { Thing: } \\
\text { LS: } \\
\text { MOUNTAIN } \\
\text { LS: BUILDING }\end{array}$ & \\
\hline & & & USING ALL LIMBS & $\begin{array}{l}\text { LS: TREE } \\
\text { LI: ladder } \\
\text { LI: drainpipe } \\
\text { LI: scaffolding }\end{array}$ & \\
\hline & & & $\begin{array}{l}\text { USING ALL LIMBS } \\
\text { UP AND OVER }\end{array}$ & LS: BARRIER & \\
\hline (b) & & & ON FOOT & $\begin{array}{l}\text { LS: STAIR } \\
\text { LS: PATH }\end{array}$ & \\
\hline (c) & LS: VEHICLE & $\begin{array}{l}\text { GO UPWARD } \\
\text { SLOWLY }\end{array}$ & ON WHEELS & LS: PATH & \\
\hline (d) & LS: PATH & UPWARD & State & LS: PATH & \\
\hline (e) & LS: HUMAN & $\begin{array}{l}\text { Event } \\
\text { GO UPWARD } \\
\text { WITH EFFORT } \\
\text { SLOWLY }\end{array}$ & $\begin{array}{l}\text { UP MOUNTAIN } \\
\text { USING ALL LIMBS }\end{array}$ & 0 & \\
\hline (f) & LS: PLANE & GO UPWARD & THROUGH AIR & 0 & $\begin{array}{l}\text { (ADVERBIAL } \\
\text { from SOURCE } \\
\text { to GOAL) }\end{array}$ \\
\hline (g) & LS: VAPOUR & GO UPWARD & THROUGH AIR & 0 & $\begin{array}{l}\text { (ADVERBIAL } \\
\text { from SOURCE } \\
\text { to GOAL) }\end{array}$ \\
\hline (h) & LS: sun & $\begin{array}{l}\text { GO UPWARD } \\
\text { PERCEIVED }\end{array}$ & & 0 & \\
\hline (i) & LS: PLANT & GROW UPWARD & AROUND THING & 0 & \\
\hline (j) & $\begin{array}{l}\text { LS: HUMAN } \\
\text { LS: ANIMAL }\end{array}$ & $\begin{array}{l}\text { Event } \\
\text { GO WITH } \\
\text { EFFORT }\end{array}$ & USING ALL LIMBS & 0 & $\begin{array}{l}\text { ADVERBIAL } \\
\text { from SOURCE } \\
\text { via PATH to } \\
\text { GOAL }\end{array}$ \\
\hline$(\mathrm{k})$ & LS: PATH & UPWARD & State & 0 & $\begin{array}{l}\text { ADVERBIAL } \\
\text { from SOURCE } \\
\text { via PATH to } \\
\text { GOAL }\end{array}$ \\
\hline (l) & LS: ABSTRACT & $\begin{array}{l}\text { Event } \\
\text { BECOME } \\
\text { GREATER } \\
\end{array}$ & & (AMOUNT) & $\begin{array}{l}\text { (ADVERBIAL } \\
\text { by AMOUNT } \\
\text { to AMOUNT) }\end{array}$ \\
\hline
\end{tabular}

\section{Table 1. Prototype for CLIMB (Hanks 1994).}

11 The abbreviation "comb." in the heading of column 3 indicates that the listed features are implied by the combination of subject, verb and object. 


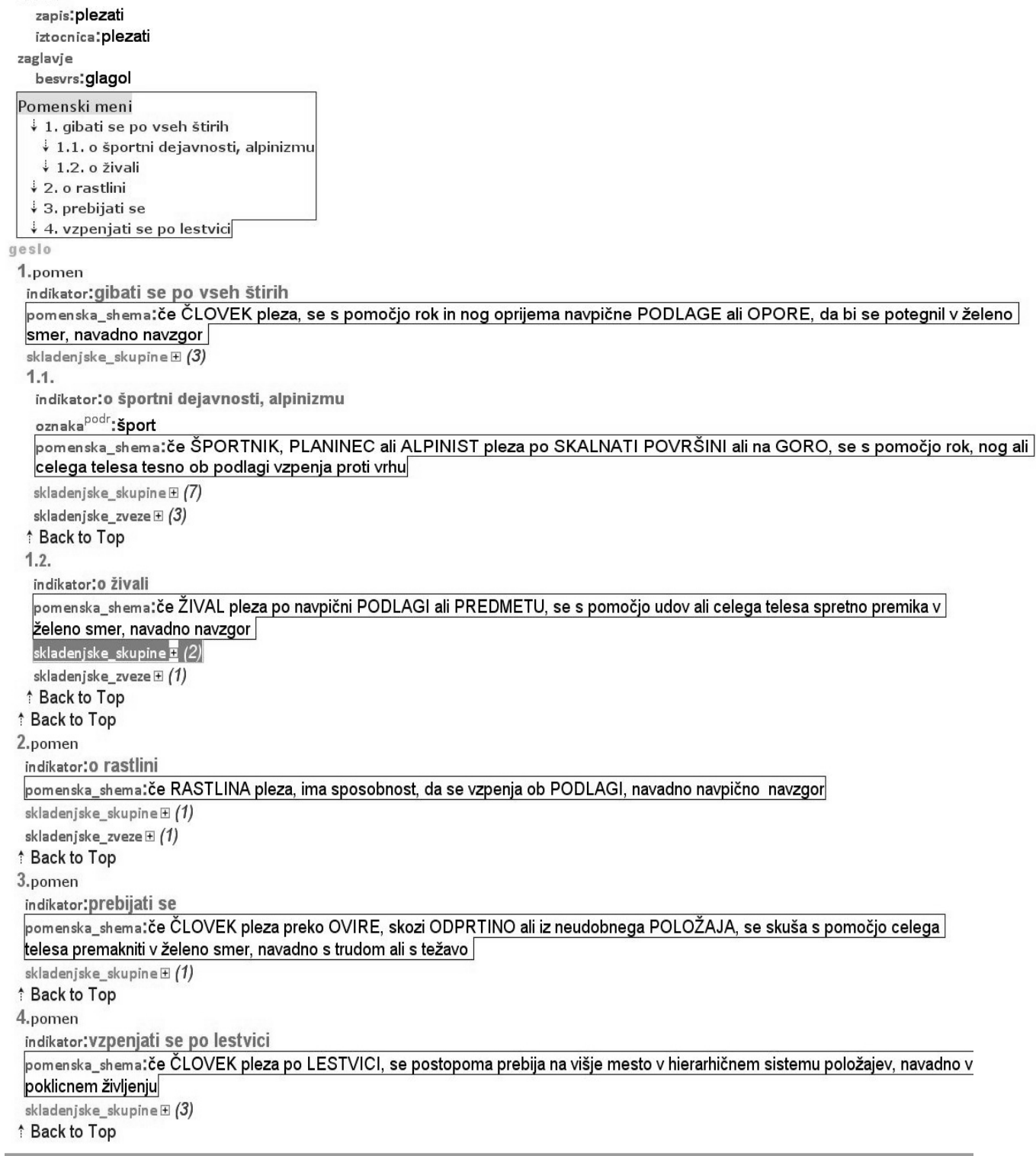

\section{Figure 1. The entry for PLEZATI in the SLD. ${ }^{11}$}

Along the lines of Hanks's prototype model, the entry structure for plezati, which covers some uses of the verb $\lim b$ but not all, can be schematically represented in terms of obligatory and optional participants, and circumstances as identified in the SLD (see Table 2). The starting point for the representation of the 'prototype' is the actual 'uses' with (grammatically) predictable syntactic patterns (e.g., S V O) to which meanings are attached, while the representation in the SLD is primarily concerned with meaning, so that the identified 'uses' are subsumed under the individual senses and subsenses (as indicated below in the left-most column). In other words, the semantic-

\footnotetext{
11 To aid understanding, in the present paper all of the examples from the SLD are translated into English. Although sometimes
} awkward, the translations are intentionally as literal as possible, so that the original wordings remain evident. 


\begin{tabular}{|c|c|c|c|c|c|c|}
\hline & $\begin{array}{l}\text { Obligatory } \\
\text { participants }\end{array}$ & $\mathrm{V}$ & $\begin{array}{l}\text { Obligatory } \\
\text { participants }\end{array}$ & Combined & $\begin{array}{l}\text { Obligatory/ } \\
\text { optional } \\
\text { circumstances }\end{array}$ & Patterns \\
\hline 1 & LS: HUMAN & $\begin{array}{l}\text { Event } \\
\text { go upward }\end{array}$ & $\begin{array}{l}\text { LS: SURFACE } \\
\text { or SUPPORT } \\
\text { (ladder, trees, } \\
\text { rocks, rope) }\end{array}$ & $\begin{array}{l}\text { using all } \\
\text { limbs } \\
\text { (arms, legs) }\end{array}$ & $\begin{array}{l}\text { to the desired } \\
\text { destination, } \\
\text { goal }\end{array}$ & $\begin{array}{l}\text { 1) sb climbs; } \\
\text { 2) sb climbs over sth; } \\
\text { 3) sb climbs } \\
\text { somewhere*; } \\
\text { 4) sb climbs over sth }\end{array}$ \\
\hline 1.1 & $\begin{array}{l}\text { LI: SPORT- } \\
\text { SPERSON, } \\
\text { MOUNTAIN- } \\
\text { EER }\end{array}$ & $\begin{array}{l}\text { go upward } \\
\text { slowly }\end{array}$ & $\begin{array}{l}\text { LS: } \\
\text { MOUNTAIN }\end{array}$ & $\begin{array}{l}\text { using all } \\
\text { limbs }\end{array}$ & $\begin{array}{l}\text { to top of (?), } \\
\text { close to the } \\
\text { surface }\end{array}$ & $\begin{array}{l}\text { 1) sb climbs; } \\
\text { 2) sb climbs over sth; } \\
\text { 5) sb climbs towards } \\
\text { sth; } \\
\text { 6) sb climbs to sth; } \\
\text { 7) sb climbs on sth; } \\
\text { 8) sb climbs in sth; } \\
\text { 9) sb climbs sth }\end{array}$ \\
\hline 1.2 & $\begin{array}{l}\text { LS: ANIMAL } \\
\text { (squirrel, } \\
\text { spider) }\end{array}$ & go upward & $\begin{array}{l}\text { LS: SURFACE } \\
\text { or OBJECT }\end{array}$ & $\begin{array}{l}\text { using all } \\
\text { limbs }\end{array}$ & $\begin{array}{l}\text { with ease (and } \\
\text { fast ?) }\end{array}$ & 10) sth climbs over sth \\
\hline 2 & $\begin{array}{l}\text { LS: PLANT } \\
\text { (ivy, climbing } \\
\text { plant) }\end{array}$ & $\begin{array}{l}\text { grow } \\
\text { upward? }\end{array}$ & $\begin{array}{l}\text { AROUND } \\
\text { or ALONG } \\
\text { SURFACE, } \\
\text { SUPPORT } \\
\end{array}$ & & & 10) sth climbs over sth \\
\hline 3 & LS: HUMAN & $\begin{array}{l}\text { move } \\
\text { over, out, } \\
\text { through }\end{array}$ & $\begin{array}{l}\text { LS: BARRIER } \\
\text { (fence), } \\
\text { OPENING } \\
\text { (window), } \\
\text { uncomfortable } \\
\text { POSITION }\end{array}$ & $\begin{array}{l}\text { using all } \\
\text { limbs }\end{array}$ & with effort & $\begin{array}{l}\text { 2) sb climbs over sth; } \\
\text { 11) sb climbs from } \\
\text { sth; } \\
\text { 12) sb climbs out of } \\
\text { sth; } \\
\text { 5) sb climbs towards } \\
\text { sth; } \\
\text { 13) sb climbs through } \\
\text { sth }\end{array}$ \\
\hline 4 & LS: HUMAN & $\begin{array}{l}\text { move } \\
\text { upwards }\end{array}$ & $\begin{array}{l}\text { LS: SOCIAL } \\
\text { LADDER }\end{array}$ & & $\begin{array}{l}\text { in } \\
\text { professional, } \\
\text { social life }\end{array}$ & $\begin{array}{l}\text { 14) sb climbs up } \\
\text { (literally) sth }\end{array}$ \\
\hline
\end{tabular}

\section{Table 2. The schematic representation of the lexical profile for PLEZATI in the SLD.}

syntactic information contained in Hanks's 'uses' is represented here on two separate levels: in semantic-syntactic meaning descriptions where semantic types are explicated and (typically) placed in their typical syntactic roles, as well as in potentially recurring syntactic patterns devoid of semantic types or any lexical information (see the Patterns column on the right). 
Due to the differences in the theoretical approach, along with, of course, the interlingual, i.e., contrastive differences, the resulting lexicographical profile is different, but reflects the key semanticsyntactic components in a similar way. Once the semantic-syntactic components have been identified, they can be grouped together in various ways to represent meanings, or rather, meaning potentials. In the continuation, we shall summarise the overlapping as well as the differences in the two schematic representations of meaning, of which the first (Hanks's prototype) takes grammar, i.e., syntactic functions, and the second (SLD) takes meaning as its organising principle:

Pattern 1 (SVO): The central uses of the climb prototype are those in which the subject is a human or animal and the direct object is a thing (mountain, building, tree, barrier, stair or path). This pattern largely corresponds to sense no. 1 in plezati (the direct object in this use is expressed as a prepositional object in Slovene). Within the listed lexical set, there is a further distinction between, e.g., a mountain, for which there is an implication that one intends to reach its top, and a tree, where such an implication is less obvious. This distinction is given prominence at the level of subsense in plezati:

\subsection{SPORT}

if a SPORTSPERSON or a MOUNTAINEER climbs up a ROCKY SURFACE or a MOUNTAIN, s/he uses her/his limbs or her/his whole body to get to the top, closely leaning against the surface

A predominant feature of Pattern 1 for $\operatorname{climb}$ is that the climber uses all his/her limbs except where the subject is either a vehicle or a path. These uses are not realised by the verb plezati but by a near-synonym vzpenjati se in Slovene, where the focus in vzpenjati se is less on the physical aspects or manner of climbing, but more on the act of 'moving upwards'. The correspondence between the senses of vzpenjati se and those of climb will not be treated here.

Pattern 2 (SV[A]): In the most central use of a null-object alternation, "the default interpretation 'suppressed direct object: mountain' is subsumed" (Hanks 1994). In fact, as semantic rather than formal syntactic patterning is given priority, this use is listed as one of the syntactic patterns under subsense 1.1 in plezati, which best illustrates the difference in the two principles of sense organisation. All of the obligatory, but suppressed participants are explicated in the semantic-syntactic description, while the actual realisations (also with omissions) are listed as syntactic patterns.

Pattern 3 (SVA): The subject is a human or animal, and there is an adverbial complement usually rendered as a prepositional phrase. This use is semantically, and also grammatically, paralleled in plezati (Hanks's adverbial content is identified as obligatory) with sense 3:

3 if a HUMAN climbs over an OBSTACLE, through an OPENING, or from an uncomfortable POSITION s/he, using all limbs and her/his whole body, attempts to move in the desired direction, usually with great difficulty or with some effort

Both traditional English and Slovene dictionaries have failed to record a crucial fact or circumstance of usage, which is the difficulty and effort involved in performing the action of climbing in this sense. The component 'going upwards' is not nearly as central as 'moving (in any direction) with effort' and this is a signal that we are dealing with a set of quite different (pragmatic) circumstances.

Pattern 4 (SV[A]): This pattern consists of an abstract subject, such as prices or temperature, and the meaning is 'rise on a scale'. "There are optional adverbial complements expressing the amount 
by which something becomes greater and/or the level that it reaches" (Hanks 1994). In Slovene, this use is realised by a corresponding sense in the synonymous vzpenjati se. However, in plezati there is a use with the prepositional object listed as sense 4, which is absent from Hanks's prototype but closely related to the one described, namely 'climbing in the social rank or scale':

4 if a HUMAN climbs up in the SOCIAL SCALE s/he gradually makes her/his way up in the hierarchical ordering of positions or ranks

\subsection{Pragmatics and definition strategies}

The SLD was compiled with two aims in view: the formalisation of syntactic structures and patterns for purposes of NLP and a description of lexicographically relevant facts. The present paper is concerned primarily with the area of lexical analysis that highlights the role of pragmatic aspects of meaning and, at the same time, when focused on pragmatic components of meaning, helps to understand how meaning is formed at the various levels of language structure. As pragmatic literature attests (e.g., Verschueren 2000), there is no structural level of language that could be regarded as devoid of pragmatic implication, and there are linguistic phenomena that we can study from the perspective of language use at any level of language structure. The focus here is narrowed to those instances which encode pragmatic meaning as part of their meaning rather than those whose inherent function is to be overtly attitudinal or to express subjective evaluation, i.e., that which is traditionally subsumed under connotation or the speaker's attitude (e.g., swear words, pejorative and offensive language, praise, etc.). Instead, our interests lie in the way the pragmatic (functional) meaning that arises from various contextual features can become an integral part of lexicographical descriptions.

\subsubsection{Circumstances of meaning}

Pragmatic information is often located in the circumstances of meaning. In the SLD meaning descriptions, pragmatic components are considered prominent indicators of meaning (nuances) and often play an important role in the process of sense discrimination ${ }^{12}$ (the material is grouped into standard senses and subsenses). The examples show that this type of information - typically on cause, reason, intention, manner or other circumstances of meaning - is quite naturally and consistently located in the semi-formalised parts of descriptions beginning in 'usually' (also 'especially'), which provide typical situations of meaning. Introducing typical rather than obligatory participants and circumstances, this strategy is adopted analogously in many monolingual dictionaries, including COBUILD3, MEDAL2, LDOCE4 and MWLD.

\subsection{Semantic prosody}

Semantic prosodies add meaning that goes beyond the meaning already expressed by wordsemantics, requiring a close examination of contexts of use and components of meaning that are not always detectable in the immediate surroundings of the headword, or, as Philip (2009) puts it, "[I]n short, the semantic prosody associated with a lexical item communicates an attitudinal, evaluative or emotional stance with regard to a particular concept or scenario and its outcome (anticipated or actual), not simply a vague and ill-defined 'aura of meaning'", as ensuing from an ethereal, but more frequently cited, definition of semantic prosody by Louw (1993, 157): "a consistent aura of meaning with which a form is imbued by its collocates." According to Sinclair

12 In the meaning of (my) place (i.e., the place where I live), Sinclair (1996, 83-93) identifies the prosody 'informal invitation' in patternings that differentiate one meaning of place (home) from others. 
$(1996,34),{ }^{13}$ a semantic prosody expresses attitudinal meaning and is on the pragmatic side of the semantics/pragmatics continuum: "it shows how the rest of the item is to be interpreted functionally." The fact that semantic prosody is somewhat elusive and not always present has given some linguists, Whitsitt (2005) in particular, reason to discard it as "a figment of corpus linguists' imaginations". However, semantic prosody, like meaning on the whole, cannot be identified purely with introspection. As Louw explicitly states: "semantic prosodies are a collocational phenomenon and one which is preferably to be regarded as recoverable computationally from large language corpora rather than intuitively" $(2000,48)$. Their role is to connect the meanings expressed by particular wordings with the context of situation, linking them inseparably to the phrasing and spreading over the entire unit of meaning (which is why Sinclair referred to it as a 'prosody' in the first place according to Philip 2009, citing Sinclair 2003, 117). In the Slovene linguistic community, a good overview of the notion of semantic prosody and its role in lexical semantics has been given by Gabrovšek (2007), who also points out a deficient treatment of this phenomenon in contemporary dictionaries. In fact, it emerges that semantic prosodies are often difficult to describe in more complex terms than those of a simple positive/negative polarity. Nevertheless, in the SLD, we have aimed to explicate prosodic meaning by providing detailed descriptions of circumstances recoverable from corpus examples. The fact that this, as a rule, increases the length and complexity of the descriptions has not been considered a drawback at this stage of compilation:

SLD: if a HUMAN equates SOMETHING with a PHENOMENON, CONCEPT, or CHARACTERISTIC s/he thinks that they are the same things, usually failing to see the difference either as a result of ignorance or intentionally

\section{SI: če ČLOVEK enači KAJ s POJAVOM, POJMOM ali LASTNOSTJO, meni, da gre za enake stvari, pri tem pa navadno spregleda bistvene razlike, bodisi zaradi nevednosti ali namerno}

While semantic prosodies are often equated with so-called 'semantic preference', some studies (Philip 2009) have shown that the term semantic prosody can be used loosely, incorporating what, in effect, are two different levels of meaning analysis, of which the first is lexical, affective and abstracted from semantic preference (=connotational meaning), while the second is delexical, functional, phraseological and abstracted from various contextual features (=pragmatic function, as summarised in the underlined part of the definition above). By bringing the associations back into a real context of situation, the second facet of semantic prosody is inextricably pragmatic in nature: where, when, why and to whom something means what it does (ibid.). To fill what seems to be a conceptual and terminological gap between semantic preference and semantic prosody, a new category is proposed by Philip (2009), namely 'semantic association', advanced originally by Hoey $(2005,16 \mathrm{ff}$.) to subsume "two different concepts, sometimes confused with each other" (Hoey 2005, 22), i.e., semantic preference and semantic prosody. If the term 'semantic association' is adopted as a separate category, Sinclair's (1996) quadripartite extended unit of meaning can be split into five: collocation, colligation, semantic preference, semantic association, and semantic (pragmatic) prosody. However, despite a theoretically sound argument in favour of 'semantic association' it is, in practice, not always possible to distinguish clearly between semantic prosody and association.

\subsubsection{Semantic prosody, phraseology and idiomaticity}

The criteria of semantic (non-)analysability considerably affect the way in which functional aspects of meaning, i.e., semantic prosody, come into play in phraseology. Phraseology is understood here in

13 Semantic prosody was first used and presented to the research community by Sinclair (1996) and Louw (1993). 
the broadest possible sense as a fundamental organising principle of language, also called by Sinclair the 'idiom principle', which is contrasted with its counterpart, the 'open choice principle', also present but in a way less indicative of the way language actually works. In fact, one of the more significant findings of corpus linguistics is that most language is phraseological and that it is only rarely combined freely. Unlike the non-compositionality characteristic of all conventional phraseological units, "[m] eaning that the combination of words used in the sequence that they are used is not generated anew out of the grammar every time it is required, but is instead pre-constructed and thus available for use as a single lexical choice" (Philip 2009), semantic (non-)analysability is central to idiomaticity: the degree to which it is possible to grasp the meaning of a lexical unit on the basis of the meaning of its component parts. In the continuation, we shall provide a practical analysis of a selection of extended units of meaning and examine the relationship between semantic prosody, phraseology and idiomaticity, as determined by degrees of semantic analysability.

\subsubsection{Meaning as a matter of attitude towards a pragmatic situation}

\section{Example 1: plezati (čez/skozi kaj; iz česa) - climb (over/through/from sth)}

As seen above (2.1.2.1), in the listed sense 3 of plezati, 'make one's way through/over/out of an uncomfortable position with effort', a set of circumstances has been identified that differ quite considerably from sense 1 . The conceptual condition 'clamber' is most fully present here. The subject is typically human, and the act of climbing largely unplanned or undesired, or rather desperate in an attempt to reach a particular goal. This situation of meaning is a good example of how semantic prosody comes into play in the process of sense discrimination:

SLD 3: if a HUMAN climbs over an OBSTACLE, through an OPENING, or from an uncomfortable POSITION s/he, using all limbs and her/his whole body, attempts to move in the desired direction, usually with great difficulty or with some effort

SI: ČLOVEK pleza preko OVIRE, skozi ODPRTINO ali iz neudobnega POLOŽAJA, se skuša s pomočjo celega telesa premakniti v želeno smer, navadno s trudom ali težavo

SSKJ $2^{14}$ : premikati se, pomagajoč si z nogami in rokami, tako, da je telo blizu podlage (to move, using legs and arms, with the body close to the surface)

All of the examples of usage contain some element that indicates unfavourable circumstances surrounding the central event, accessible through the speaker's attitude, which is not at all typical of climbing a ladder, a tree or a mountain; therefore, a separate sense is in place to capture adequately the identified pragmatic components.

\footnotetext{
- Zaposleni v studiu morajo včasih plezati prek kupov daril, plenic in različnih igrač

- Tu in tam je pot zasuta, morava plezati po razritih obvozih.

- Hoditi je potrebno in mestoma plezati po strmih travah, grobem grušču, ostrih pečeh in policah.

- Med snemanjem namreč ne moreš plezati s tribun in iskati stranišče.

- Kuga. Vidi svojo mati, še vedno živo, in začne plezati proti njej. A stražar ga spet sune med rebra, potegne za noge, zgrabi

za lase in povleče stran.

- Zakaj ne pokukajo v Ulico Stare pravde, da ne bodo starši z bolnimi otroci do vhoda bolnišnice plezajo čez pločevino

- Tedaj so razjarjeni navijači na zahodni tribuni začeli plezati čez ograjo, ob igrišče, kjer sta bila sodnika, pa so začeli leteti

predmeti.

- Tisoči so skušali priti na prepoln stadion tako, da so plezali prek ograj in zaprtih vrat

- Velikokrat so morali plezati skozi okna, iskati stranske izhode in pred dekleti pobegniti skozi kuhinjo.

- Zračna blazina se je že izpraznila in osvobodila pritisk na moje telo. Počasi sem se odvezal in pričel plezati iz vozila - skozi

sovoznikovo okno!
}

\section{Figure 2. The examples for the most typical 'clambering' sense (='prebijati se'). See translations below.}

This is a sense in SSKJ that only partly evokes the corresponding meaning. 
- The studio personnel must sometimes climb over heaps of presents, nappies and various toys.

- The track is in parts unsurpassable, we have to climb up on the dug up deviations.

- It is necessary to walk and in some parts to climb on steep grassy slopes, rough gravel, and sharp rocks.

- During the shooting one cannot climb from the stadium seats and look for the toilets.

- The pest. He can see his mother, still alive, and starts to climb towards her. But the guard pokes him in the rib again, pulls him by the legs, grabs his hair and drags him away.

- Why don't they peek into the Stara Pravda Street, so that parents with children who are ill don't have to climb over all the cars outside.

- At that point, the angry supporters at the west stand began to climb over the fence, while objects were being thrown to the area next to the play field where the referees were.

- Thousands tried to come into the stadium climbing over the fences and closed gates.

- Often they would have to climb through the windows, the side exits and run away from the girls through the kitchen.

- The airbag had already emptied itself and released the pressure on my body. I slowly unfastened the safety belt and started climbing out of the vehicle - through the co-driver's window!

The most common collocates are 'fence, barrier, window, vehicle', and the verb is noticeably used with the modal verb 'must' or impersonal constructions 'it is necessary to' etc., as well as with the verb 'start'. The semantic preference is for all kinds of barriers and obstacles or narrow openings, from which the association of difficulty, effort and helplessness can be derived. Finally, we can posit the semantic prosody of anguish or despair arising from the frustration at not being able to move faster or with greater ease, also annoyance with one's helplessness or anger with those who caused it. There are indeed indications that the situation is sometimes due to human negligence or inability, as well as to objective circumstances. An important (negative) prosodic element is that conveying a vast discrepancy between what is expected in a normal situation and what is.

\begin{tabular}{|l|l|l|l|l|}
\hline Collocates & Colligates & Preference & Association & Prosody \\
\hline $\begin{array}{l}\text { Fence (ograja), } \\
\text { Window (okno), } \\
\text { Vehicle (vozilo), } \\
\text { Barrier (ovira) }\end{array}$ & $\begin{array}{l}\text { Modal and incoative } \\
\text { verbs (must, start to); } \\
\text { Impersonal modal } \\
\text { constructions (it is } \\
\text { necessary to) }\end{array}$ & $\begin{array}{l}\text { Barriers, (Narrow) } \\
\text { openings, Obstacles, } \\
\text { Difficult terrain }\end{array}$ & $\begin{array}{l}\text { Difficulty, Effort; } \\
\text { Helplessness }\end{array}$ & $\begin{array}{l}\text { Anguish or despair } \\
\text { arising from the } \\
\text { frustration of not } \\
\text { being able to move } \\
\text { faster; Annoyance } \\
\text { with one's helplessness } \\
\text { and anger with the } \\
\text { people who caused it }\end{array}$ \\
\hline
\end{tabular}

Table 3. Summary of the unit of meaning with PLEZATI (preko, skozi, iz) as node.

SSKJ only lists 3 meanings, none of which correspond fully to the 'with effort' or the 'clambering' component of meaning. While LDOCE4 evokes a related sense in the 'slowly and awkwardly' part of the definition 3, neither MEDAL2 nor the DANTE lexical database give this sense special prominence. COBUILD3, on the other hand, identifies a sense with the components 'carefully', 'a small space', 'trying to avoid falling' which can, at least conditionally, be associated with 'clambering'. 


\subsubsection{Meaning as a matter of emphasis}

\section{Example 2: bobnati (=biti bobnar) - to drum}

The way meaning and use are in fact two distinct, yet inseparable, facets of language is illustrated by the analysis of the following example, which shows how meaning can arise from an emphasis on a particular aspect of the (pragmatic) situation rather than from the word's inherent (semantic) features. Semantic prosody in some cases relies more heavily on the colligates than the collocates alone, "if anything tending to favour the patterns and participants in verbal processes over lexicalsemantic features per se" (Philip 2009). The prototypical meaning, though not the most frequent meaning, of bobnati is defined by most (Slovene and English) sources within the framework below:

SLD 2: if a HUMAN drums s/he plays an instrument by making a continuous beating sound either by hands or special objects

SI: če ČLOVEK bobna, igra na instrument tako, da s pripomočkom ali rokami ustvarja ritem

SSKJ: udarjati, igrati na bobne (to beat on, to play drums)

The MLDs only list very short definitions for this sense of drum, e.g., 'to beat or play a drum, or a set of drums' (MWLD) or 'to play a drum' (MEDAL2, LDOCE4), while COBUILD3 does not list this general sense at all. The metaphorical meanings are more prominent, such as 'to drum sth home' or 'to beat/bang the drums about sth', etc. Some examples of the salient meaning of bobnati from the SLD, 'to play a drum/drums', are listed below. This meaning of the verb is characterised by intransitive use and prepositional complementation often describing the instrument itself. The semantic association as well as prosody is neutral, as the salient meaning of the verb seems to be communicatively sufficient.

- The driller Žiga got acquainted with the waitress Tina that day, after which he set up the Rhythm Thieves group, and she learned how to drum.

- That's when we meet Guy Patterson, who during the day makes his living as a shop assistent, while he spends the nights enthusiastically drumming.

- These two caves, the Mala and Velika Bobnarica, have a strange name like this for a reason, for if there is thunder in the sky a sound comes from them like that of a drummer drumming on a big old drum.

\begin{tabular}{|l|l|l|l|l|}
\hline Collocates & Colligates & Preference & Association & Prosody \\
\hline Learn (naučiti se); & Verbs with incoative & Expressions related to & Neutral & Neutral \\
Drum (boben); & function; Adverbial pre- & drummers and other \\
Drummer (bobnar) & and postmodification; & players of instruments; & & \\
& $\begin{array}{l}\text { Prepositional } \\
\text { complementation (drums); } \\
\end{array}$ & & & \\
& Adverbs of manner & & & \\
\hline
\end{tabular}

\section{Table 4. Summary of the unit of meaning with BOBNATI as node.}

However, apart from the basic lexical meaning, on close examination and driven by a pragmatic function of meaning, a subsense can be separated out in bobnati that is more naturally expressed in English as 'to be sb's drummer', i.e., to play drums in a particular band or group on a regular basis: 
b)*: if a HUMAN drums s/he is engaged in playing the drums as a regular member of a music group, usually for a period of time

SI: če ČLOVEK bobna, se posveča igranju na bobne kot stalni član glasbene zasedbe, navadno v določenem obdobju

- The new drummer is Nenad Kostadinovski, who used to drum with groups such as Scuffy Dogs and Traffic Religion.

- Do you then have a drummer for your concerts? At the concerts we use Moreno Buttinar, who is Lara Baruca's drummer. We have also practiced with Janez, who drums with Miladojka Youneed.

- Meanwhile, Eva and Nataša sing and drum on Laibach's concert tour, while Darja has used the short period of lesser working intensity really well and has freshly fallen in love.

- Micky Waller, who first wanted to learn rock'n'roll drumming, later on drummed with Little Richard, Jeff Beck in Rod Stewart.

- Cecil Durkin was a druggy, a knife cutter and a prison rapist, but he also drummed in a few good jazz bands.

This use of the verb is distinct, as its colligational behaviour in particular indicates: it typically requires explicit temporal complementation (recently, at night, later, on tour, in the election time, sometimes, etc.) or the time of the action is implied in the context by the use of, typically, a past tense. It is commonly used with prepositional complementation (drum with, at, in, etc.) denoting individual people or groups with whom one drums; proper names, therefore, appear regularly in the co-text as part of listings and/or coordinate structures with 'and'. Of course, the prototypical meaning 'to play a drum' is still present, but it is now a secondary rather than the key component of the conveyed sense. The emphasis is on the fact of being engaged as member of a performing musical group, often in the context of other players who make up the group, i.e., on the role ensuing from the ability to play the drums. Another colligational feature is that the verb cannot be pre- or postmodified, e.g., by an adverb. The semantic preference is for musical groups, players and settings, from which the association of an opportunity for success and fame emerges. The semantic prosody here seems to lie first and foremost in "renewing the connection of this semantic information with the reality of language in use [... ]" (Philip 2009). Potentially, one could detect a certain nuance of pride ensuing from an active role of the participants in the musical scene.

\begin{tabular}{|c|c|c|c|c|}
\hline Collocates & Colligates & Preference & Association & Prosody \\
\hline $\begin{array}{l}\text { Prepositions: at } \\
\text { (pri), in (v), on (na); } \\
\text { Begin (začeti), stop } \\
\text { (nehati) }\end{array}$ & $\begin{array}{l}\text { Usu. 3. person; } \\
\text { Temporal complementation; } \\
\text { Complementation of 'fellow } \\
\text { players' (proper names); } \\
\text { Incoative verbs; } \\
\text { Coordinate structures, listing; } \\
\text { No adverbial premodification }\end{array}$ & $\begin{array}{l}\text { Musical groups, } \\
\text { Musicians, } \\
\text { Musical scene }\end{array}$ & $\begin{array}{l}\text { Opportunity, } \\
\text { Success, Fame; } \\
\text { Pride }\end{array}$ & $\begin{array}{l}\text { Pride ensuing } \\
\text { from an active role } \\
\text { in a (more or less) } \\
\text { established band } \\
\text { or musical scene?; } \\
\text { Bringing to the } \\
\text { fore the functional } \\
\text { (pragmatic) } \\
\text { meaning }\end{array}$ \\
\hline
\end{tabular}

Table 5. Summary of the unit of meaning with BOBNATI (pri, $v, z)$ as node. 
Pragmatics plays an important role in phraseology, as well as in some types of word-formation processes, and is typically reflected in multi-word units such as compounds. Semantic prosody is present depending on the need of a word meaning to be supplemented by pragmatic meaning in language-based communication. Unlike the meaning of compositional and semantically analysable language - which, wholly accounted for by word meaning, by definition is not patterned "because it has no need of patternings to fix meaning which is 'inherent' in the words themselves" - meaning that is to a greater extent idiomatic requires greater involvement of the semantic prosody (Philip 2009).

Example 3: kisel (sour, astringent)

kislo vreme (sour/grey/dull weather)

kislo zelje (sauerkraut)

kislo jabolko (lit. 'the sour apple (of sth)')

\subsubsection{Restricted meaning in semantically analysable units: collocation}

a) kislo vreme (sour/grey/dull weather)

Semantic analysability can be observed along a continuum stretching from collocations commonly thought to be transparent, but so only in their restricted meanings, i.e., in only one of the possible meanings resulting from the various meanings of their components, as well as of their various combinations - to the most opaque idioms that lie at the other extreme (Philip 2009). The above collocation can therefore be observed in its restricted meaning 'dull weather':

SLD: sour WEATHER is when it rains or the sky is overcast

SI: kislo VREME je takrat, ko ni sonca ali dežuje

SSKJ ekspr.: kislo vreme - neprijetno, pusto (unpleasant, dull)

The only two collocates that stand out are 'zagosti' and 'pokvariti' ('to spoil'), paralleled in scarcity by colligational patterns. The semantic preference is for cultural and sports events, and, within a limited spectrum, for agricultural products, especially grapes. The semantic association of physical and mental discomfort caused by the weather conditions helps build up the semantic prosody based on imminent danger of poor turnouts at public events or people not going ahead with their outdoor plans, such as tourists cancelling their bookings:

- A general characteristic is that the camping sites in Gorenjska are pretty full, and even the sour weather of recent days has not chased away the tourists.

- That is why the construction workers are working at a good pace, but, on the other hand, due to sour weather the owners of Bioterme are in no hurry to open the swimming pool.

- The expected sour weather will cause malaise or indisposition in many people.

An important fact about kislo vreme is that it is often used with its verbal collocates to express the opposite, i.e., to convey that unfavourable conditions did not, in fact, have the expected effect and did not put people off from coming and/or having a good time. Colligationally, therefore the use of negation is noticeable: 
- The good spirits were not destroyed even by somewhat sour weather, which towards noon cleared up, so they set off for short or longer walks in the surrounding areas, some over to Gospodična, after which they continued to enjoy each other's company right until nightfall.

Another set of preference is instantiated by collocates referring to fruits, such as grapes, that are expected to ripen and develop sugar in the sun. This use represents an additional meaning dimension with a play on words, as 'kisel' strongly implies the actual (sour) taste of unripe grapes:

- When the summer is sunny and September alike, the grapes will be sweet, but sour weather will give us grapes that will be hard to sell.

\begin{tabular}{|c|c|c|c|c|}
\hline Collocates & Colligates & Preference & Association & Prosody \\
\hline $\begin{array}{l}\text { Ruin, spoil (zagosti, } \\
\text { pokvariti); Rainy } \\
\text { (deževen), Cold } \\
\text { (hladen) }\end{array}$ & $\begin{array}{l}\text { Clause final } \\
\text { punctuation; } \\
\text { Often in the } \\
\text { negative; } \\
\text { Coordinate } \\
\text { structures with } \\
\text { 'and' }\end{array}$ & $\begin{array}{l}\text { (Cultural and } \\
\text { Sports) Events; } \\
\text { Socialising; } \\
\text { Agricultural } \\
\text { products }\end{array}$ & $\begin{array}{l}\text { Unpleasant, } \\
\text { unfavourable } \\
\text { circumstances; Mood } \\
\text { swings; Physical and } \\
\text { mental discomfort; }\end{array}$ & $\begin{array}{l}\text { Imminent danger of } \\
\text { cancellations, poor } \\
\text { attendance; at events; } \\
\text { Cancelled outdoor } \\
\text { plans, holidays; } \\
\text { Conveying the } \\
\text { unexpected }\end{array}$ \\
\hline
\end{tabular}

\section{Table 6. Summary of the unit of meaning with KISLO VREME as node.}

\subsubsection{Meaning as encyclopaedic knowledge: (terminological) compounds}

b) kislo zelje (sauerkraut)

There are some words and phrases that cannot be understood without knowledge of the real world or so-called encyclopaedic knowledge, such as compounds that convey different degrees of (semi) terminological meaning that has to be learned. A discrete indication of semantic non-analysability related to terminological use in this case is an unpredictable foreign language equivalent, in English: sauerkraut.

The MLDs are unanimous in explaining the unit by referring to its German origin, to the vegetable (cabbage) it is made from and to the procedure involved. Collocates denoting the form in which kislo zelje is used or served are identified, often in constructions expressing quantity or quantification. The recipe format presupposes listing other foods and vegetables, leading to many coordinate structures which make up typical colligational patterns. The semantic preference is overtly for cooking recipes or eating habits, a clear association being that of health and culinary delights. The semantic prosody in this case is neutral (or not detectable).

\begin{tabular}{|c|c|c|c|c|}
\hline Collocates & Colligates & Preference & Association & Prosody \\
\hline $\begin{array}{l}\text { Raw (surovo), Grated } \\
\text { (ribano), Sliced } \\
\text { (narezano); Kilo } \\
\text { (kilogram), Ton (tona); } \\
\text { Little (malo), More } \\
\text { (več) }\end{array}$ & $\begin{array}{l}\text { Quantity; } \\
\text { Quantification; Listing, } \\
\text { coordinate structures } \\
\text { with other kinds of } \\
\text { vegetables }\end{array}$ & $\begin{array}{l}\text { Cooking (recipes); } \\
\text { Shopping for food; } \\
\text { Eating habits; }\end{array}$ & Health & Neutral \\
\hline
\end{tabular}

Table 7. Summary of the unit of meaning with KISLO ZELJE as node. 


\subsubsection{Meaning as (pragmatic) knowledge about language use: idiomatic expressions}

In some expressions, where the salient (or metaphorical) meaning of either of words is insufficient for the reader to know their overall meaning, "word-semantics are redundant and yield entirely to the pragmatic reality of use, both textual and contextual, as the meaning of the phrase relies heavily on knowledge of semantic associations and semantic prosody" (Philip 2009):

c) kislo jabolko (česa)

SLD: a known problem or the heart of a dispute

ugrizniti/zagristi v kislo jabolko (česa) - lit. 'to bite the sour apple (of sth)' (to bite (on) the bullet)

SLD: means that sb willingly starts to deal with a known problem or unpleasant circumstances, conscious of the difficulties that might emerge

SI: pomeni, da se nekdo načrtno sooči z znanim problemom ali neprijetnimi okoliščinami, zavedajoč se težav, ki ga čakajo

SSKJ: lotiti se česa neprijetnega, neugodnega (to start dealing with something unpleasant)

The MLD explanations of the corresponding 'to bite the bullet' lay emphasis on 'sth difficult or dangerous' and the fact that it is 'the beginning of sth'. It is worth pointing out the two meaning components that only COBUILD3 gives special prominence to in its description, namely 'accept that' and 'but necessary' (MWLD also identifies 'necessary'). Although the phraseological core kislo jabolko (česa) can stand alone - and therefore deserves an independent meaning description - it typically collocates with 'ugrizniti' ('bite (on)'). Again, colligational patterns are quite prominent, such as the premodification of the core by an adjective or a quantifier:

- Only the fourth judge Tanja Rot 'bit the legal sour apple' and called for a first hearing at the Maribor District Court last Friday.

postmodification typically realised by a genitive or a relative clause:

- Money is a 'sour apple' into which every year in early spring the Ribnica councillors must bite (the bullet into which ... must bite).

and constructions expressing comparison or intensification, as well as modal preference for obligation or inevitability:

- 'The sourest apple' that must be bitten by the member candidates is direct subsidies, as in the financial perspectives of the EU until 2006 not a single Euro was set aside for the new member states with this purpose

Scare quotes are relatively common, as is the case with many metaphorical expressions:

- Considering that each and every role of the Big Jack is a special experience, we do not doubt that sooner or later you will bite this 'sour apple'.

The semantic preference is for difficult situations, and the associations linked to it are difficulty, challenge and a necessary evil. A semantic prosody resting heavily on colligation can be posited: 
coping with the inevitability and accepting to tackle a problem because it can no longer be put off. On the whole, familiarity with the situation somewhat alleviates the unpleasant consequences.

\begin{tabular}{|c|c|c|c|c|}
\hline Collocates & Colligates & Preference & Association & Prosody \\
\hline $\begin{array}{l}\text { Bite (ugrizniti, } \\
\text { zagristi); Sour } \\
\text { (kislo), Sweet } \\
\text { (sladko); Must } \\
\text { (morati) }\end{array}$ & $\begin{array}{l}\text { Pre- and } \\
\text { postmodification } \\
\text { (genitive, relative } \\
\text { clauses); } \\
\text { Comparison, } \\
\text { intensification; Modal } \\
\text { verbs expressing } \\
\text { obligation; Scare quotes }\end{array}$ & $\begin{array}{l}\text { Difficult situation, } \\
\text { Tough conditions }\end{array}$ & $\begin{array}{l}\text { Problem, Difficulty, } \\
\text { Challenge, } \\
\text { Necessary evil }\end{array}$ & $\begin{array}{l}\text { Urgency, } \\
\text { Necessity, } \\
\text { Acceptance to } \\
\text { tackle a problem } \\
\text { because it can no } \\
\text { longer be put off }\end{array}$ \\
\hline
\end{tabular}

\section{Table 8. Summary of the unit of meaning with KISLO JABOLKO as node.}

\subsubsection{Summary}

The above described (extended) units of meaning vary in the degree to which each of their individual categories, including semantic prosody, contributes to the overall meaning. In principle, idiomatic expressions depend more on associations and pragmatic (functional) aspects of meaning than do semantically analysable units of language, such as collocations. Of the three analysed units in example 3 , kislo zelje as a (semi)terminological unit seems to draw the least on prosodic features, while (ugrizniti) $v$ kislo jabolko is largely dependent on a knowledge of its associations and semantic prosody.

\section{Conclusion}

It is important in the description of meaning to identify the degree to which pragmatics plays a role in the formation of the particular meaning in order to provide an adequate semantic-pragmatic description. The methods of corpus analysis have shown that semantic prosody can be investigated systematically by observing recurring patterns of (contextual) meaning. Semantic prosody builds along the semantics/pragmatics continuum and is a result of empirically identifiable elements of the meaning structure, albeit on the furthest boundaries of a lexical unit of meaning. This has farreaching implications for the way lexicographical descriptions of meaning are constructed. Pragmatic information, including semantic prosody, is an integral part of an (extended) unit of meaning. What is obvious in the process of lexical analysis is the difficulty of describing semantic prosody in a way that goes beyond a simple positive or negative evaluation. The SLD meaning descriptions reveal an ambition to do just that. Prosody may be difficult to describe lexicographically, but when present it is an integral part of the wording that cannot be severed from the co-text or context. In our view, it is vital in a lexical database to provide all of the information on the headword that is retrievable from the corpus data; semantic prosody, no doubt, is that kind of information.

\section{Bibliography}

Atkins, S. 2010. The DANTE Database: Its Contribution to English Lexical Research, and in Particular to Complementing the FrameNet Data. In A Way with Words: Recent Advances in Lexical Theory and Analysis. A Festscrift for Patrick Hanks, ed. G.-M. de Schryver, 267-97. Kampala: Menha Publishers.

Atkins S., and M. Rundell. 2008. The Oxford Guide to Practical Lexicography. Oxford: Oxford University Press.

Atkins, S., C. Fillmore, and C.R. Johnson. 2003. Lexicographic Relevance. Selecting information from corpus 
evidence. International Journal of Lexicography, 16, no. 3: 251-80.

Barnbrook, G. 2002. Defining language: A local grammar of definition sentences. Studies in Corpus Linguistics. Amsterdam: John Benjamins Publishing Company.

Fillmore, C. 1982. Towards a Descriptive Framework for Spatial Deixis. In Speech, Place, and Action, ed. R.J. Jarvella and W. Klein, 31-59. Chichester: John Wiley and Sons.

Fillmore, C., and S. Atkins 1992. Towards a frame-based organization of the lexicon: the semantics of RISK and its neighbors. In Frames, Fields, and Contrasts, ed. A. Lehrer and E.F. Kittay, 31-59. Hillsdale, NJ: Lawrence Erlbaum Associates.

Fillmore, C., C.R. Johnson, and R.L. Petruck. 2003. Background to Framenet. International Journal of Lexicography, 16, no. 3: 235-50.

Gabrovšek, D. 2005. Words Galore. Aspects of General and Slovenian-English Contrastive Lexicology. Filozofska fakulteta Univerze v Ljubljani/Oddelek za anglistiko in amerikanistiko.

- - -. 2007. Connotation, Semantic Prosody, Syntagmatic Associative Meaning: Three Levels of Meaning? ELOPE IV, no. 1-2: 9-28.

Gantar, P., K. Grabnar, P. Kocjančič, S. Krek, O. Pobirk, R. Rejc, M. Šorli, S. Šuster, and P. Zaranšek. 2009. Standard for the Compilation of a Lexical Unit (Indicator 6): Communication in Slovene Project: Style Guide: the Slovene Lexical Database. Kamnik. Slovenia. Available at: http://www.slovenscina.eu/Media/Kazalniki/ Kazalnik6/SSJ Kazalnik 6 Specifikacije-leksikalna-baza v1.pdf (Accessed 6 September 2012).

Halliday, M.A.K. 1966. Lexis as a Linguistic Level. In In Memory of J. R. Firth, ed. C.E. Bazel, J.C. Catford, M.A.K. Halliday, and R.H. Robins, 148-62. London: Longman.

Halliday, M.A.K., and C. Yallop. 2007. Lexicology. A Short Introduction. London \& New York: Continuum.

Hanks, P. 1987. Definitions and explanations. In Looking up. An Account of the COBUILD Project, ed. J.M. Sinclair, 116-36. London and Glasgow: Collins ELT.

- - - 1994. Linguistics Norms and Pragmatic Exploitations, or Why Lexicographers Need Prototype Theory, and Vice Versa. In Papers in Computational Lexicography: Complex '94, ed. F. Kiefer, G. Kiss and J. Pajsz, 89-113. Budapest: Hungarian Academy of Sciences.

- - - 2004. Corpus Pattern Analysis. In Proceedings of the 11th EURALEX International Congress, Volume I, ed. G. Williams and S. Vessier, 87-97. Lorient, Université de Bretagne Sud.

- - . 2013. Lexical Analysis: Norms and Exploitations. Cambridge, MA: MIT Press.

Hoey, M. 2005. Lexical Priming. London and New York: Routledge.

Jackendoff, R. 1990. Semantic structures. MIT Press.

Louw, B. 2000. Contextual Prosodic Theory: Bringing Semantic Prosodies to Life. In Words in Context: A tribute to John Sinclair on his retirement, ed. C. Heffer and H. Sauntson, 48-94. Birmingham: University of Birmingham.

Louw, W.E. 1993. Irony in the Text or Insincerity in the Writer?: The Diagnostic Potential of Semantic Prosodies. In Text and technology: in honour of John Sinclair, ed. M. Baker, G. Francis and E. Tognini Bonelli, 157-76. Amsterdam: Benjamins.

Philip, G. 2009. Why Prosodies Aren't Always There: Insights into the Idiom Principle. Corpus Linguistics Conference. Liverpool. Great Britain. http://ucrel.lancs.ac.uk/publications/cl2009/ (Accessed 6 September 2012).

Rosch, E., and B.B. Llyod. 1978. Cognition and Categorization. Lawrence Erlbaum Associates.

Sinclair, J.M. ed. 1987. Looking Up: Account of the Cobuild Project in Lexical Computing (Collins Cobuild dictionaries). London and Glasgow: Collins ELT. 
- - - 1991. Corpus, Concordance, Collocation. Oxford: OUP.

- - 1996. The Search for Units of Meaning. TEXTUS 9, no. 1: 75-106.

-- - 2004. Trust the Text: Language, Corpus, and Discourse. Routledge.

Stubbs M. 2001. On Inference Theories and Code Theories: Corpus Evidence for Semantic Schemas. In Text, 21, no. 3: 436-65.

Šorli, M. 2011. Pragmatic Components in the Slovene Lexical Database Meaning Descriptions. In Electronic lexicography in the 21st century: new applications for new users: proceedings of eLex 2011, 10-12 November 2011, Bled, Slovenia, ed. I. Kosem and K. Kosem, 251-9. Ljubljana: Trojina, zavod za uporabno slovenistiko.

Taylor, J.R. 1989. Linguistic Categorization: Prototypes in Linguistic Theory. Oxford: OUP

Verschueren, J. 2000. Razumeti pragmatiko. (The original: Understanding Pragmatics, 1999). Ljubljana: Založba/*ff (Transl. by I. Prosenc).

Whitsitt, S. 2005. A Critique of the Concept of Semantic Prosody. International Journal of Corpus Linguistics 10: 283-305.

\section{Dictionaries and Databases}

Collins COBUILD English Language Dictionary. $1^{\text {st }}$ edn. Sinclair, JMcH., Hanks, P. eds. 1987. London: HarperCollins (COBUILD1).

Collins COBUILD English Language Dictionary. $2^{\text {nd }}$ edn. Sinclair, JMcH. ed. 1995. London: HarperCollins (COBUILD2).

Collins COBUILD English Dictionary for Advanced Learners (on CD-ROM). $3^{\text {rd }}$ edn. Sinclair, JMcH. ed. 2001. Glasgow: HaarperCollins Publishers (COBUILD3).

The DANTE Database. Accessed at: http://www.webdante.com/

Longman Dictionary of Contemporary English Online, Longman. Accessed at: http://www.ldoceonline.com/ (LDOCE).

Longman Dictionary of Contemporary English (on CD-ROM). $4^{\text {th }}$ edn. Summers, D. ed. 2003. Harlow, Longman. (LDOCE4)

Macmillan Dictionary and Thesaurus: Free English Dictionary Online. Oxford: Macmillan Education. Accessed at: http://www.macmillandictionary.com/.

Macmillan English Dictionary for Advanced Learners. $2^{\text {nd }}$ edn. Rundell, M. ed. 2007. Oxford: Macmillan Education (MEDAL2).

Merriam Webster's Learner's Dictionary. Accessed at: http://www.learnersdictionary.com/ (MWLD).

The Slovene Lexical Database (SLD). Accessed at: http://www.slovenscina.eu/spletni-slovar

Web sites

http://nlp.fi.muni.cz/projekty/cpa/.

http://framenet.icsi.berkeley.edu/.

www.fidaplus.net.

http://www.slovenscina.eu/spletni-slovar

(All links accessed 24 October 2013). 